\title{
Reactivity of polynuclear zinc-thiolate sites
}

\author{
Gilles Ohanessian, Delphine Picot, Gilles Frison* \\ Laboratoire des Mécanismes Réactionnels, \\ Département de Chimie, Ecole Polytechnique and CNRS, \\ 91128 Palaiseau Cedex, France. \\ Fax: + $0033(0) 169334803$ \\ gilles.frison@polytechnique.org
}

\begin{abstract}
The proton affinities of a series of mono- and polynuclear zinc-thiolate compounds, mimicking zing finger protein and metallothioneins sites, have been investigated by Density Functional Theory calculations. This allows to evaluate the intrinsic nucleophilicity of synthetic and natural zinc-bound thiolates and to compare their relative reactivities. The site specificity of the experimental thiolate alkylation for the $\mathrm{Zn}_{4} \mathrm{Cys}_{11}$ clusters in metallothioneins is well reproduced, as well as the relative reactivities of $\mathrm{ZnHis}_{2} \mathrm{Cys}_{2}, \mathrm{ZnHisCys}_{3}$ and $\mathrm{ZnCys}_{4}$ zinc finger sites. Our results also show that terminal thiolates, bound to only one Lewis acid, are more reactive than bridging thiolates. Synthetic inorganic clusters and the $\mathrm{Zn}_{4} \mathrm{Cys}_{9} \mathrm{His}_{2}$ cluster found in a cyanobacterial metallothionein are less reactive than $\mathrm{Zn}_{4} \mathrm{Cys}_{11}$ and $\mathrm{Zn}_{3} \mathrm{Cys} 9$ clusters in metallothioneins. These results allow discussing the influence of the protein backbone and residues on the reactivity of these natural clusters.
\end{abstract}

Keywords: zinc, metallothioneins, nucleophilicity, computational chemistry, S ligands 


\section{Introduction}

Metallothioneins (MTs) are low molecular weight, cysteine-rich, metal-binding proteins that are found ubiquitously in nature. They have naturally-occurring $\mathrm{Zn}^{2+}$ in metal-thiolate clusters and can coordinate a large number of other metal ions, including $\mathrm{Cd}(\mathrm{II})$ and $\mathrm{Cu}(\mathrm{I})$ [1][2][3]. The fundamental roles of MTs in biological systems have yet to be determined. A number of functional roles have been proposed so far, including metal ion homeostasis and detoxification, as well as protection against reactive oxygen species [4][5].

MTs generally coordinate zinc ions in two distinctive cluster arrangements, the $\mathrm{Zn}_{3} \mathrm{Cys}_{9}$ and the $\mathrm{Zn}_{4} \mathrm{Cys}_{11}$ clusters, located respectively in the $\beta$ - and $\alpha$-domain of vertebrate class I MTs [6][7][8]. Both of them include end-on zinc-thiolate and bridging zinc-thiolate-zinc coordinations (Scheme 1). Class II MTs exhibit greater structural diversity as revealed by the sequences of these proteins [9]. However, detailed knowledge on zinc coordination environment is sparse. A four-metal ion cluster in which two histidine residues participate in metal ion coordination, resulting in a $\mathrm{Zn}_{4} \mathrm{Cys}_{9} \mathrm{His}_{2}$ arrangement, has been described in a cyanobacterial MT [10]. Very recently, a mononuclear Zn binding site constituted by two cysteine and two histidine residues has been found in a plant MT [11]. In all cases, each zinc ion has four ligands.

These structural characteristics find some parallel in zinc finger $(\mathrm{ZF})$ proteins. Indeed, the $\mathrm{Zn}^{2+}$ ion in $\mathrm{ZF}$ has a tetrahedral coordination involving at least two cysteine thiolates while the remaining two ligands are either Cys or His residues (Scheme 1). Besides this chemical composition similarity, both redox and nucleophilic reactivities have been observed for mononuclear ZF and polynuclear MT sites. Despite the redox inactivity of the $\mathrm{Zn}^{2+}$ cation, the $\mathrm{Zn}-\mathrm{S}$ (Cys) moiety is redox-active in biology [12][13]. This has been enlightened by Maret and Vallee for metallothioneins [14][15][16] and for "structural-like" zinc sites in ZF proteins [17]. It has to be noticed that other cysteine-containing zinc centers with a $\mathrm{ZnCys}_{4}$ or a $\mathrm{ZnCys}_{3} \mathrm{His}$ core, like the molecular chaperone Hsp33 and the anti-sigma factor RsrA, respectively, possess redox activity [18][19][20].

Zinc sites in ZF, as well as other "structural-like" zinc sites like the $\mathrm{ZnCys}_{4}$ site in the Ada DNA repair protein [21], have been shown to promote the alkylation of a zinc-bound thiolate [22][23]. Based on studies on biomimetic zinc complexes [24], both the thiolate reactivity [25][26] and the reaction mechanism [27] have been shown to be dependent upon the nature of the zinc ligands. The reactivity of $\mathrm{Zn}(\mathrm{SPh})_{4}{ }^{2-}$ against dimethyl sulfoxide was thus found to decline dramatically as successive thiolate ligands were replaced by neutral imidazole ligands 
[28]. It has to be noticed that this intrinsic reactivity of a "bare" zinc site is also modulated by the protein environment [29]. This characteristics has been used to synthesize anti-HIV agents that selectively target retroviral nucleocapsid protein zinc fingers without affecting cellular zinc finger proteins [30][31]. Furthermore, two thiolates from the same site can afford diverse reactivities, according to their individual molecular interactions. This is the case for the $\mathrm{ZnCys}_{4}$ site of the Ada DNA repair protein and for the $\mathrm{ZnHisCys}_{3} \mathrm{C}$-terminal site of the Ncp7 zinc finger, which are alkylated specifically on Cys38 [32] and Cys49 [33] respectively.

MTs react with a variety of electrophilic agents, from DTNB [34] to anticancer chemotherapeutic drugs like the nitrogen mustard alkylating agents chlorambucil [35], melphaban [36] and mechlorethamine [37]. As zinc finger does [38], they also react with platinum drugs [39], which is thought to be a cause of resistance in cancer treatment [40][41]. These studies reveal that the reaction may be located in either the $\mathrm{Zn}_{4} \mathrm{Cys}_{11}$ or the $\mathrm{Zn}_{3} \mathrm{Cys} 9$ clusters, depending upon the electrophilic agents[34]. Furthermore, mass spectrometry studies indicate that Cys48 is the most reactive thiolate for alkylation in the $\mathrm{Zn}_{4} \mathrm{Cys}_{11}$ cluster of rat MT-2 [35][36][37].

Given the importance, underlined above, of these proteins for therapeutics aspects, we decided to evaluate the intrinsic reactivity of a variety of mono- or polynuclear zinc-thiolate sites. This will allow to compare the reactivity of these sites, as well as to determine the most nucleophilic thiolate in a given site. The reactivity of zinc-bound thiolates is evaluated by their proton affinity (PA) which has been shown to linearly correlate with their nucleophilicity [42]. 
(A)<smiles>[R5][R]([R5])([R5])I</smiles><smiles>[R5][R]([R5])([R5])[InH]</smiles><smiles>[R5][R]([R5])([InH])[InH]</smiles>

(B)<smiles>[R5][R]1([R5])S[R]([R5])([R5])[R]1([R])[R5]</smiles><smiles>[R5][R]([R5])([R5])[R]([R])([Y7])[In]</smiles>

(C)<smiles>[R5][R]1[R]([R5])([R5])S[R]([R5])([R5])[R]([R5])([R5])[R]1([R])[R5]</smiles>

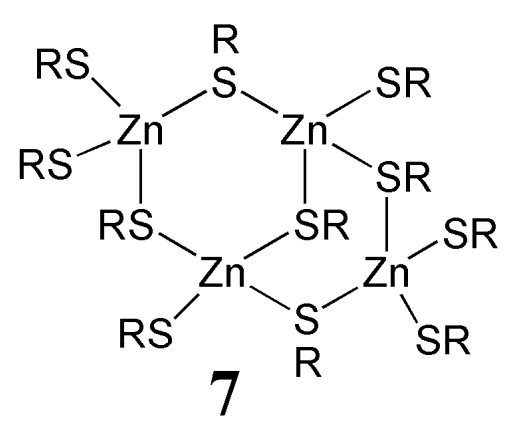

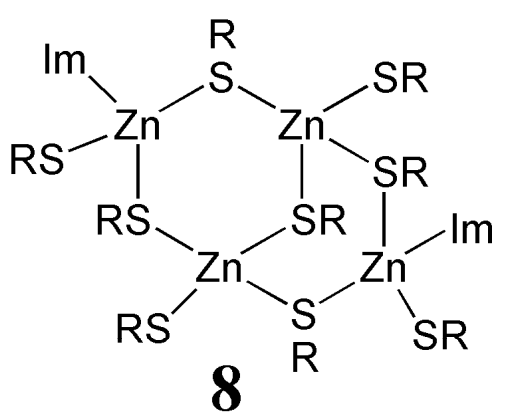

(D)<smiles>[R][R]([R5])[Se]</smiles>

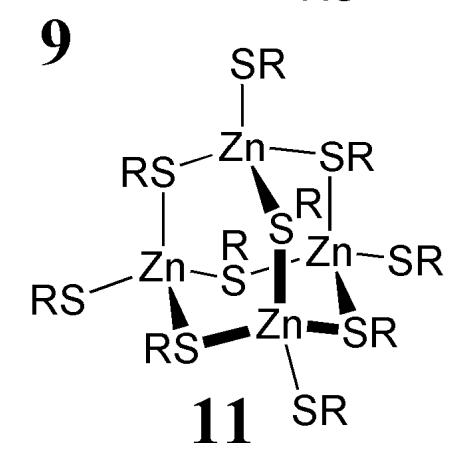

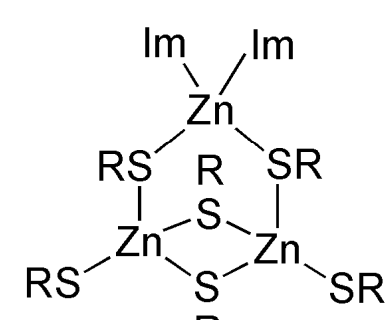

R 10

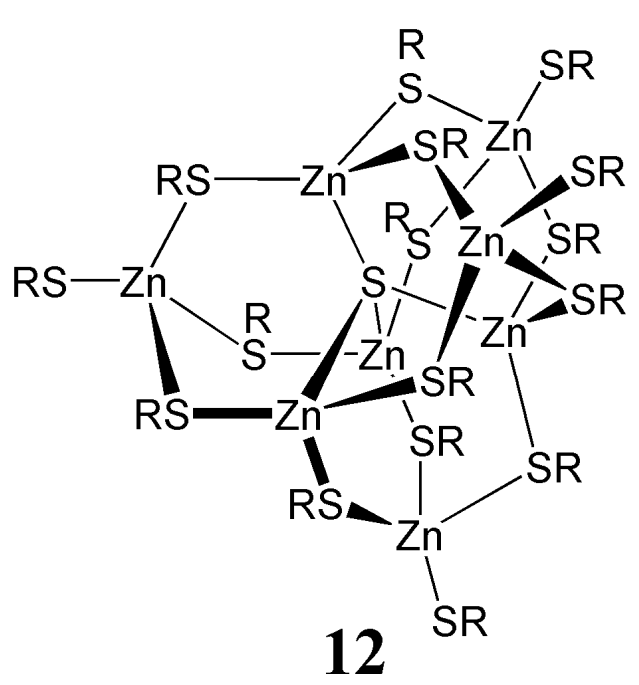

Scheme 1. Mono- and polynuclear zinc-thiolate sites examined in this work. (A) zinc finger sites (B) Gal4 and Rag1 dimerization domain dinuclear sites (C) metallothionein sites (D) synthetic inorganic clusters. 


\section{Methods}

We use a well established methodology [43][44][45], the GGA density functional BP86 [46][47][48], for geometry optimization of all systems. This functional has been shown to give reasonable optimized $\mathrm{Zn}-\mathrm{S}$ and $\mathrm{Zn}-\mathrm{N}$ bond lengths in numerous studies of zinc complexes ([49][50][51][52]). In order to speed up the calculations, the Multipole Accelerated Resolution of Identity for $\mathrm{J}$ (MARI-J) approximation method [53], as implemented in Turbomole [54], has been used. Basis sets of split valence quality, labelled def2-SVP [55][56], and the associated auxiliary basis sets to fit Coulomb potentials [57], were employed for all atoms for geometry optimization.

Each stationary point has been characterized with vibrational frequency analysis, which confirmed the lack of imaginary frequencies. The calculated frequencies were scaled with 0.9914 [58] and used to obtain zero-point energy corrections, enthalpies and entropies.

Improved energies were obtained by single-point calculations at the B3LYP level [59][60], with the extended basis set of polarized valence triple zeta quality, labeled def2-TZVPP [56][61]. For an additional gain in speed, the resolution of identity (RI) approximation was used. This functional has been shown to give reliable relative energetical data for zinc complexes compared to other density functionals or post-HF calculations.[62][63][64][65]

Solvation free energy corrections were determined using the conductor-like screening model (COSMO)[66] which is a polarizable continuum solvation model. The COSMO calculations were carried out on the gas phase MARIJ-BP86/def2-SVP geometries, at the B3LYP/def2TZVPP level, with a dielectric constant $\varepsilon$ of 78.4 .

\section{Results and discussion}

\section{Studied models}

Scheme 1 displays the mono- and polynuclear zinc-thiolate systems studied in this work. Besides models $\mathrm{Zn}\left(\mathrm{SCH}_{3}\right)_{4}{ }^{2-} \mathbf{1}, \mathrm{Zn}(\mathrm{Im})\left(\mathrm{SCH}_{3}\right)_{3}{ }^{-} \mathbf{2}(\mathrm{Im}=$ imidazole $)$ and $\mathrm{Zn}(\mathrm{Im})_{2}\left(\mathrm{SCH}_{3}\right)_{2} \mathbf{3}$ of the mononuclear zinc finger sites and $\mathrm{Zn}_{3}\left(\mathrm{SCH}_{3}\right)_{9}{ }^{3-} \mathbf{6}, \mathrm{Zn}_{4}\left(\mathrm{SCH}_{3}\right)_{11}{ }^{3-} 7$ and $\mathrm{Zn}_{4}(\mathrm{Im})_{2}\left(\mathrm{SCH}_{3}\right)_{9}{ }^{-}$ $\mathbf{8}$ of the polynuclear metallothioneins sites, several other $\mathrm{Zn}$-thiolate clusters have been included. Two additional types of zinc-thiolate clusters, namely the dinuclear $\mathrm{Zn}_{2}(\mathrm{Cys})_{6}$ and $\mathrm{Zn}_{2}$ (His) ${ }_{2}(\mathrm{Cys})_{5}$ sites, have been found in biology, respectively in the GAL4 type of fungal transcription factors [67] and the dimerization domain of $\mathrm{V}(\mathrm{D}) \mathrm{J}$ recombination-activating protein RAG1 [68]. They have been modelled as complexes $\mathrm{Zn}_{2}\left(\mathrm{SCH}_{3}\right)_{6}{ }^{2-} 4$ and 
$\mathrm{Zn}_{2}(\mathrm{Im})_{2}\left(\mathrm{SCH}_{3}\right)_{5}{ }^{-} 5$ respectively. Synthetic inorganic zinc-thiolate clusters are known to be precursors for preparation of nanomaterials [69] as well as to mimic ZF or MT site features [70]. To evaluate the proximity of these synthetic sites with biological ones, we include in our study four other compounds, namely $\mathrm{Zn}\left(\mathrm{SCH}_{3}\right)_{3}{ }^{-} 9$ [71][72], $\mathrm{Zn}_{3}(\mathrm{Im})_{2}\left(\mathrm{SCH}_{3}\right)_{6} \mathbf{1 0}$ [73], $\mathrm{Zn}_{4}\left(\mathrm{SCH}_{3}\right)_{10}{ }^{2-} \mathbf{1 1}$ [74][75] and $\mathrm{Zn}_{8}(\mathrm{~S})\left(\mathrm{SCH}_{3}\right)_{16}{ }^{2-} \mathbf{1 2}$ [73][75]. Among the known inorganic zinc-thiolate clusters [70], these compounds have the larger similarity with biological clusters : 9 corresponds to the monomeric part of $\mathbf{4}$ and $\mathbf{6}$; 10 includes $\mathrm{Zn}_{2} \mathrm{~S}_{2}$ square-like structure as in 4; the six-membered $\mathrm{Zn}_{3} \mathrm{~S}_{3}$ rings of 6-8 are reproduced in 10-12; 12 can be described as a dimer of $\mathbf{7}$ where the two units are fused together in a perpendicular fashion.

\section{Mononuclear zinc sites}

Optimized structures of the mononuclear $\mathrm{Zn}\left(\mathrm{SCH}_{3}\right)_{4}{ }^{2-} \mathbf{1}, \mathrm{Zn}(\mathrm{Im})\left(\mathrm{SCH}_{3}\right)_{3}{ }^{-} \mathbf{2}, \mathrm{Zn}(\mathrm{Im})_{2}\left(\mathrm{SCH}_{3}\right)_{2}$ 3 and $\mathrm{Zn}\left(\mathrm{SCH}_{3}\right)_{3}{ }^{-} \mathbf{9}$ complexes are depicted in Figure 1. The calculated proton affinities are presented in Table 1 (entries 1-3 and 19).
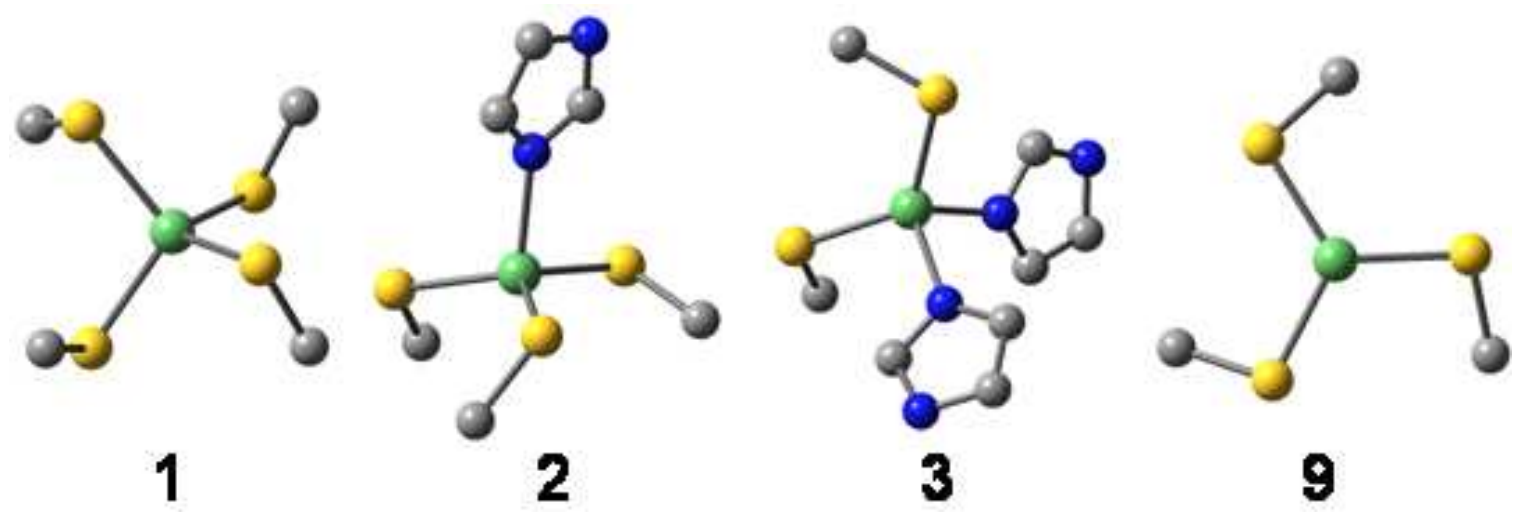

Figure 1. Structures of the mononuclear zinc complexes. Hydrogen atoms have been omitted for clarity. Color code : yellow, sulfur; blue, nitrogen; gray, carbon; green, zinc.

All thiolate groups in 1-3 and 9 are terminal coordination ligands and present the same environment within each compound. They thus have the same proton affinity, which depends on the nature of the other zinc ligands. As observed previously for biomimetic complexes [42], a thiolate ligand induces a higher nucleophilicity than a neutral nitrogen ligand like imidazole. As a consequence, the proton affinity of $\mathrm{Zn}\left(\mathrm{SCH}_{3}\right)_{4}{ }^{2-}$ is found to decline dramatically in the gas phase as successive thiolate ligands are replaced by neutral imidazole ligands, i.e. from 1 to $\mathbf{3}$. Inclusion of solvation effect reduces the difference in proton affinities between these complexes. The same trend is computed here, which nicely 
reproduces the one observed for the reactivity of biomimetic $\mathrm{Zn}(\mathrm{SPh})_{4}{ }^{2-}, \mathrm{Zn}(\mathrm{ImMe})(\mathrm{SPh})_{3}{ }^{-}$ and $\mathrm{Zn}(\mathrm{ImMe})_{2}(\mathrm{SPh})_{2}$ complexes against electrophilic agents [28].

The zinc atom in $\mathbf{9}$ has only three thiolate ligands leading to a trigonal planar coordination, contrary to all other zinc sites studied here which are tetrahedral. 9 may be view as being obtained by dissociation of one thiolate (resp. imidazole) ligand in 1 (resp. 2). In both cases, this induces a decrease of the nucleophilicity of the zinc-bound thiolate (gas phase (in solution) $\mathrm{PA}=1310(1138) \mathrm{kJ} / \mathrm{mol}$ in 9 vs 1722 (1209) and 1370 (1169) kJ/mol in 1 and 2 respectively). We can explain this trend by an increase of the Lewis acidity of $\mathrm{Zn}^{2+}$ along the fragments $\mathrm{Zn}\left(\mathrm{SCH}_{3}\right)_{3}{ }^{-}, \mathrm{Zn}(\mathrm{Im})\left(\mathrm{SCH}_{3}\right)_{2}$ and $\mathrm{Zn}\left(\mathrm{SCH}_{3}\right)_{2}$, thus leading to a larger electron transfer from the remaining thiolate group to the metal $(q(S)=-0.66,-0,64$ and -0.62 electrons for 1, 2 and 9 respectively). This binding competition between all zinc ligands, which can be visualized by the decrease of the $\mathrm{Zn}-\mathrm{S}$ bond length $(2.419,2.354$ and $2.291 \AA$ in $\mathbf{1}, 2$ and $\mathbf{9}$ respectively) leads to a decrease of the nucleophilicity of the zinc-bound thiolate.

Table 1. Proton affinities in the gas phase and in solution of compounds 1-12 and thiolate sulphur NBO charge at the B3LYP/TZVPP//BP86/SVP level.

\begin{tabular}{|c|c|c|c|c|c|c|}
\hline \multirow[t]{2}{*}{ Entry } & \multirow[t]{2}{*}{ Compound } & \multirow[t]{2}{*}{$\begin{array}{l}\text { Protonation } \\
\text { site }^{\mathrm{a}}\end{array}$} & \multirow[t]{2}{*}{$\begin{array}{l}\text { Zn-S bond } \\
\text { length }(\AA)\end{array}$} & \multicolumn{2}{|c|}{$\begin{array}{l}\text { Protonation free energy } \\
\qquad(\mathrm{kJ} / \mathrm{mol})\end{array}$} & \multirow{2}{*}{$\begin{array}{c}\text { NBO } \\
\text { Charge } \\
\mathrm{q}(\mathrm{S})\end{array}$} \\
\hline & & & & Gas phase & Solution & \\
\hline 1 & 1 & $S$ & 2.419 & 1722 & 1209 & -0.66 \\
\hline 2 & 2 & S & 2.354 & 1370 & 1169 & -0.64 \\
\hline 3 & 3 & S & 2.301 & 1044 & 1148 & -0.62 \\
\hline 4 & 4 & $S_{t}$ & 2.361 & 1589 & 1166 & -0.63 \\
\hline 5 & 4 & $\mathrm{~S}_{\mathrm{b}}$ & 2.468 & 1599 & 1165 & -0.63 \\
\hline 6 & 5 & $\mathrm{~S}_{\mathrm{t} 1}$ & 2.351 & 1401 & 1188 & -0.62 \\
\hline 7 & 5 & $\mathrm{~S}_{\mathrm{t} 2}$ & 2.328 & $-{ }^{b}$ & $-{ }^{b}$ & -0.64 \\
\hline 8 & 5 & $\mathrm{~S}_{\mathrm{b}}$ & 2.461 & $-b$ & $-b$ & -0.62 \\
\hline 9 & 6 & $\mathrm{~S}_{\mathrm{t}}$ & 2.382 & 1791 & 1175 & -0.64 \\
\hline 10 & 6 & $\mathrm{~S}_{\mathrm{b}}$ & 2.448 & 1777 & 1155 & -0.62 \\
\hline 11 & 7 & $\mathrm{~S}_{\mathrm{t} 1}$ & 2.382 & 1766 & 1188 & -0.64 \\
\hline 12 & 7 & $\mathrm{~S}_{\mathrm{t} 2}$ & 2.368 & 1730 & 1161 & -0.64 \\
\hline 13 & 7 & $\mathrm{~S}_{\mathrm{b} 1}$ & 2.434 & 1738 & 1154 & -0.61 \\
\hline 14 & 7 & $\mathrm{~S}_{\mathrm{b} 2}$ & 2.417 & 1724 & 1140 & -0.61 \\
\hline 15 & 8 & $\mathrm{~S}_{\mathrm{t} 1}$ & 2.288 & 1258 & 1136 & -0.63 \\
\hline 16 & 8 & $\mathrm{~S}_{\mathrm{t} 2}$ & 2.309 & 1309 & 1154 & -0.62 \\
\hline 17 & 8 & $\mathrm{~S}_{\mathrm{b} 1}$ & 2.406 & 1250 & 1104 & -0.63 \\
\hline 18 & 8 & $\mathrm{~S}_{\mathrm{b} 2}$ & 2.385 & 1273 & 1113 & -0.62 \\
\hline 19 & 9 & $\mathrm{~S}$ & 2.291 & 1310 & 1138 & -0.62 \\
\hline 20 & 10 & $S_{t}$ & 2.270 & 1067 & 1133 & -0.60 \\
\hline 21 & 10 & $\mathrm{~S}_{\mathrm{b} 1}$ & 2.399 & 1010 & 1085 & -0.61 \\
\hline 22 & 10 & $\mathrm{~S}_{\mathrm{b} 2}$ & 2.427 & 1051 & 1121 & -0.66 \\
\hline 23 & 11 & $\mathrm{~S}_{\mathrm{t}}$ & 2.331 & 1498 & 1147 & -0.63 \\
\hline
\end{tabular}




\begin{tabular}{lllllll}
\hline 24 & $\mathbf{1 1}$ & $\mathrm{S}_{\mathrm{b}}$ & 2.407 & 1468 & 1110 & -0.62 \\
25 & $\mathbf{1 2}$ & $\mathrm{S}_{\mathrm{t}}$ & 2.317 & 1441 & 1147 & -0.62 \\
26 & $\mathbf{1 2}$ & $\mathrm{S}_{\mathrm{b}}$ & 2.402 & 1402 & 1099 & -0.62 \\
\hline
\end{tabular}

${ }^{a}$ See figure 2 for the definition of each thiolate group. ${ }^{b}$ Not significant due to complete deformation of the site. See text for details.

\section{Polynuclear zinc sites}

Optimized structures of the polynuclear clusters 4-8 and 10-12 are depicted in Figure 2. For each zinc of all compounds, as for 1-3, a tetrahedral coordination is obtained after geometry optimization in the gas phase, in accordance with experimental structures. These zinc-thiolate clusters possess two kinds of thiolate ligands which are either "bridging" (noted $\mathrm{S}_{\mathrm{b}}$ ) between two zinc cations or "terminal" (noted $S_{t}$ ), i.e linked to only one metal. Furthermore, in several cases, two different bridging and/or terminal thiolates are present.

We will first examine the structural impact of protonation and the local reactivity of each cluster, i.e. the proton affinity of individual thiolates in each compound. The most nucleophilic sulfur of a cluster defines its reactive site and its global reactivity; these will be compared in a second step. 

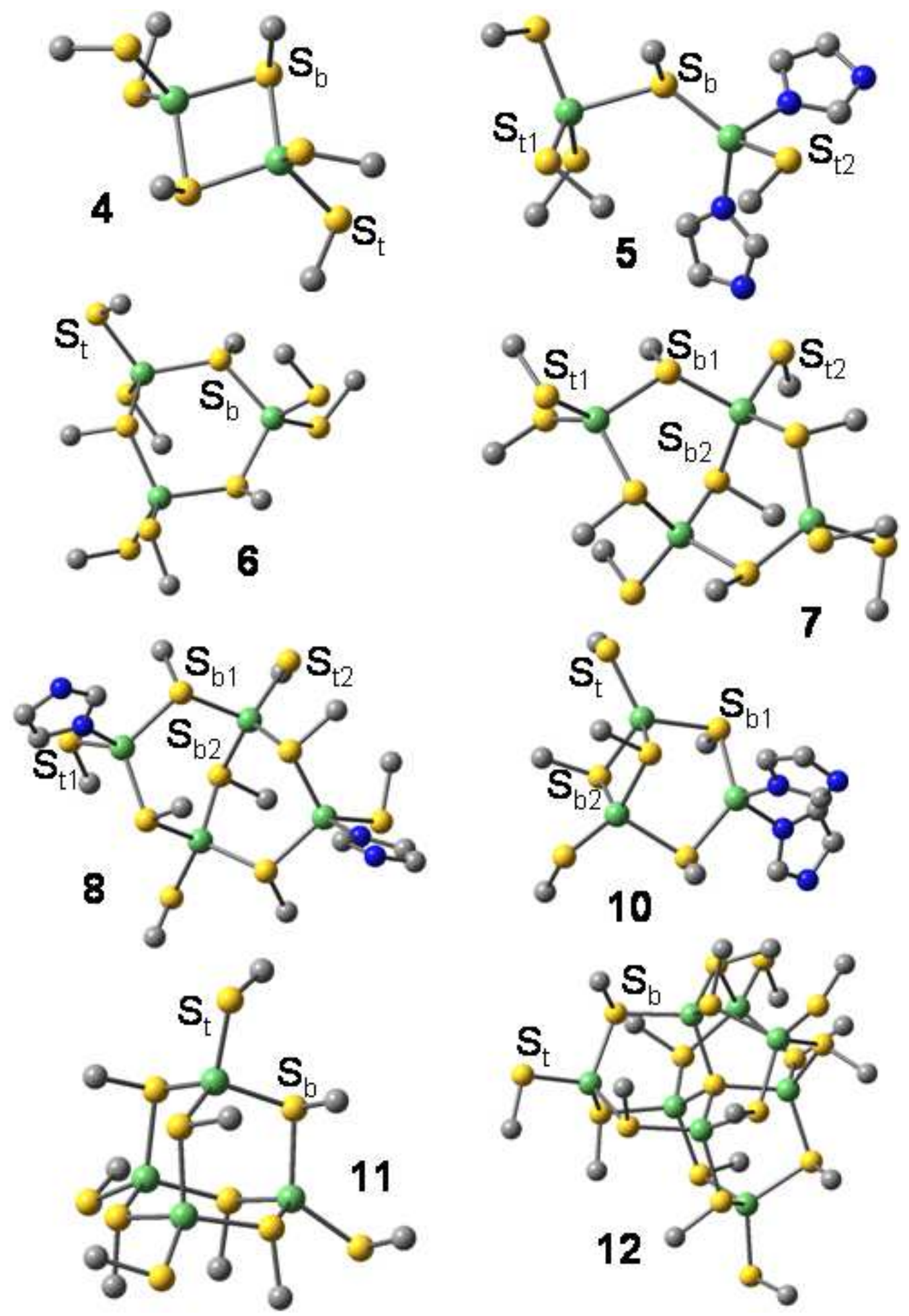

Figure 2. Structures of the polynuclear zinc clusters. Hydrogen atoms have been omitted for clarity. Color code : yellow, sulfur; blue, nitrogen; gray, carbon; green, zinc.

In all cases, protonation at sulfur induces a huge lengthening of that zinc-sulfur bond. This is illustrated for the case of $\mathbf{8}$ protonated on $S_{b 1}$, thus leading to cluster $\mathbf{8 H}_{\mathbf{b} 1}$ (Figure 3). Compared to the $2.406 \AA$ of the $\mathrm{Zn}-\mathrm{S}_{\mathrm{b} 1}$ bond length in 8 (Table 1, entry 17), a mean value of ca. $2.7 \AA$ is obtained in $\mathbf{8 H}_{\mathbf{b 1}}$ (Figure 3). In this as in most cases, the conformation of the 
cluster is not greatly disturbed by the protonation. However, in some cases $\left(\mathbf{4 H}_{\mathbf{b}}, \mathbf{5 H}_{\mathbf{b}}, \mathbf{5 H}_{\mathbf{t} \mathbf{2}}\right.$

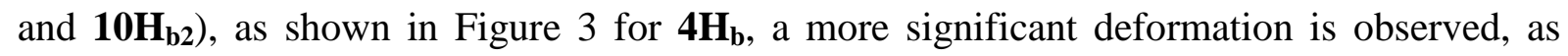
noted previously for a $\mathrm{Cu}$-thiolate cluster [76]. Complete dissociation of the protonated zinc-

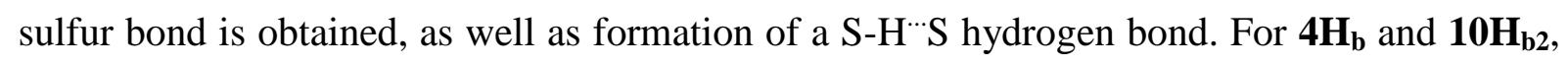
this induces the rupture of the $\mathrm{Zn}_{2} \mathrm{~S}_{2}$ square ring. We explain this result by the high ring strain in 4 and 10, compared to the six-membered rings in other clusters, which could not resist to a weakening of some of its bonds. For $\mathbf{5}$, protonation of any of the two sulfurs $S_{b}$ and $S_{t 1}$ results in dissociation of the bridge and complete reorganisation of the site. In the latter case, the proton affinity has thus not been computed. It should be noticed that the external constraints imposed in the natural cluster, modeled by $\mathbf{4}$ and $\mathbf{5}$, by the surrounding protein structure could lead to a preservation of the structure of the site in case of reaction at the above position. On the contrary, clusters 6-8 (and 10-11) are stable upon protonation. This is in agreement with experimental results which show that alkylation of MTs occurs with retention of metal ions, i.e. without large-scale distortion of the protein conformation [37]. Furthermore, this indicates that the surrounding protein structure is not a prerequisite for this retention in MT sites.

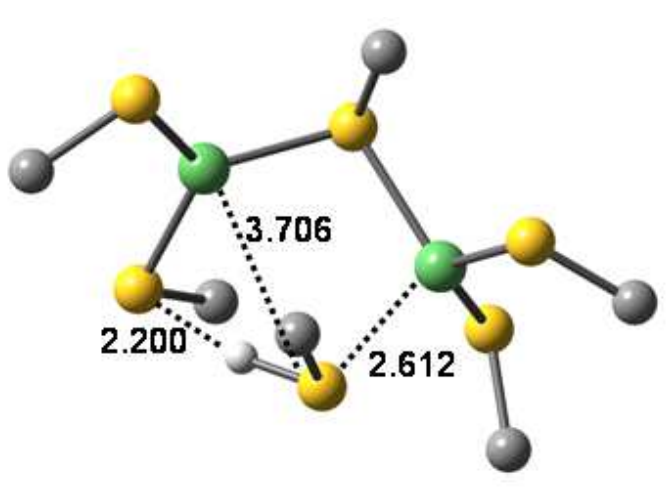

$4 \mathrm{H}_{\mathrm{b}}$

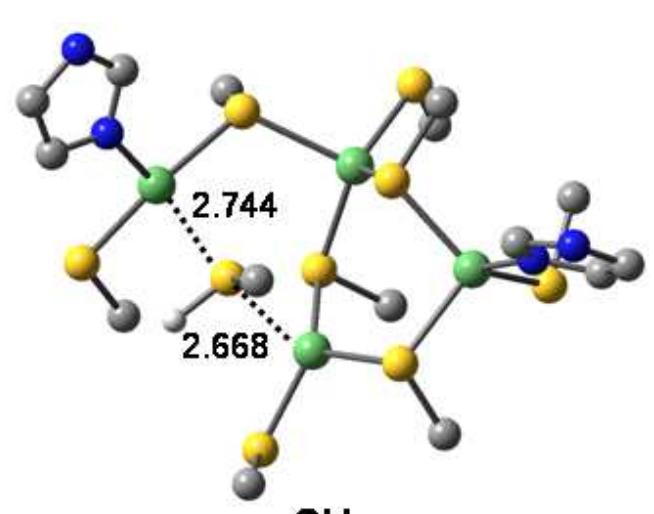

$8 \mathrm{H}_{\mathrm{b} 1}$

Figure 3. Structures of the protonated clusters $\mathbf{4 H}_{\mathbf{b}}$ and $\mathbf{8} \mathbf{H}_{\mathbf{b} 1}$. Hydrogen atoms have been omitted for clarity, except the one added to $\mathbf{4}$ and $\mathbf{8}$ respectively. Distances in $\AA$. Color code : yellow, sulfur; blue, nitrogen; gray, carbon; white, hydrogen; green, zinc.

The calculated proton affinities for the polynuclear compounds are listed in Table 1. Interestingly, for each cluster a terminal zinc-bound thiolate has a greater proton affinity than a bridging thiolate. Continuum calculations indicate this to be true in solution as well as in the gas phase. This happens in all cases except for the bridging/terminal thiolates in the $\mathrm{Zn}_{2} \mathrm{~S}_{2}$ ring of $\mathbf{4}$ where the disruption of the ring induces additional stabilisation after protonation of the bridging thiolate. The fact that a bridging thiolate is bound to two zinc cations, i.e. two strong Lewis acids, instead of only one for a terminal thiolate, may explain their difference in 
basicity. At the same time, we note that for each cluster, $\mathrm{Zn}-\mathrm{S}_{\mathrm{b}}$ bonds are always longer than the $\mathrm{Zn}-\mathrm{S}_{\mathrm{t}}$ ones. Compared to the trend observed for $\mathbf{1 , 2}$ and 9 with a decrease of both the $\mathrm{Zn}$ $\mathrm{S}$ length and nucleophilicity, this confirms that the $\mathrm{Zn}-\mathrm{S}$ length is not indicative of the reactivity of the thiolate sulfur [42]. The Zn-S length however reflects the competition between zinc ligands to bind to the metal. Indeed, sulfur to zinc electron transfer, associated with the formation of the $\mathrm{Zn}-\mathrm{S}$ bond [77][78], makes a dissociated thiolate more prone to bind to zinc (forming a terminal thiolate) than a zinc-bound thiolate (forming a bridging thiolate). Interestingly, computed electronic charges at sulfur atoms are very similar in all cases, ranging between -0.66 and -0.60 electrons. Consequently, differences on atomic charges, for example between bridging and terminal sulfur atoms, do no reflect the reactivity trends that are well fit with the proton affinities.

$\mathbf{7}$ and $\mathbf{8}$ possess two kinds of terminal and bridging thiolates. Proton affinities computed for these sites indicate the influence of the other zinc-bound ligands. The co-ligands of $S_{t 1}$ in 7 are one terminal and two bridging thiolates whereas $\mathrm{S}_{\mathrm{t} 2}$ has three bridging thiolates as partners. The competition for coordination to the zinc is thus more difficult for $S_{t 1}$ than for $S_{t 2}$. This is reflected by the longer $\mathrm{Zn}-\mathrm{S}_{\mathrm{t} 1}$ bond compared to $\mathrm{Zn}-\mathrm{S}_{\mathrm{t} 2}$. In that case, we postulate that it explains the larger proton affinity of $S_{\mathrm{t} 1}$ compared to $\mathrm{S}_{\mathrm{t} 2}: 1766$ (1188) vs 1730 (1161) $\mathrm{kJ} / \mathrm{mol}$ in the gas phase (in solution) for $\mathrm{S}_{\mathrm{t} 1}$ and $\mathrm{S}_{\mathrm{t} 2}$ in 7 respectively (entries 11 and 12 in Table 1). The opposite result is obtained for $S_{\mathrm{t} 1}$ and $S_{\mathrm{t} 2}$ sites in 8 (Table 1, entries 15 and 16), indicating that an imidazole is a weaker electron transfer competitor than a bridging thiolate.

The largest proton affinity value of $\mathbf{7}$ is obtained for the terminal $S_{t 1}$ thiolate both in the gas phase and in solution (Table 1, entries 11-14). This is in agreement with experimental results which indicate that Cys48, which is of $\mathrm{S}_{\mathrm{t} 1}$-type, is the most reactive thiolate for alkylation in the $\mathrm{Zn}_{4} \mathrm{Cys}_{11}$ cluster of rat MT-2 [35][36][37]. If the protein environment is able to differentiate between the four $\mathrm{S}_{\mathrm{t} 1}$ sites in a $\mathrm{Zn}_{4} \mathrm{Cys}_{11}$ cluster, it thus seems that the surrounding protein structure cannot modify the reactivity order between two different thiolates in a given cluster. Consequently, we predict that the most reactive site in the $\mathrm{Zn}_{4} \mathrm{Cys}_{9} \mathrm{His}_{2}$ cluster of cyanobacterial MT [10] is one of the $S_{\mathrm{t} 2}$-type thiolates.

\section{Relative reactivity of zinc sites}

Our results allow building a scale of intrinsic nucleophilic reactivity for mono- and polynuclear zinc-thiolate sites. The following decreasing orders are obtained in the gas phase and in solution : 


$$
\begin{aligned}
& 6>7>1>4>11>12>5>2>9 \approx 8>10>3 \text { (gas phase) } \\
& 1>7=5>6>2>4>8>3 \approx 11=12>9>10 \text { (in solution) }
\end{aligned}
$$

We start by examining gas phase results. As expected, we first notice that the more anionic sites are the more nucleophilic. This effect indicates large electronic delocalization in these clusters. This should happen through the sulfur to zinc electron transfer associated with the $\mathrm{Zn}-\mathrm{S}$ bond. Indeed, chemical modification of a cluster at one side induces a change in its reactivity, even if the active thiolate and its co-ligands are not modified. In other words, the indirect co-ligands of a zinc-bound thiolate, i.e. the ligands of the other zinc atoms in the cluster, play a role in its reactivity. For example, $\mathbf{1 1}$ may be viewed as the addition of the $\mathrm{Zn}\left(\mathrm{SCH}_{3}\right)^{+}$fragment onto 7. This modification of 7 induces electronic transfer from its thiolate to the added cationic fragment, thus leading to a large decrease of its reactivity.

The same effect applies when the added fragment is neutral. This is the case for example from 1 to 4 or from 6 to 7 where the $\mathrm{Zn}\left(\mathrm{SCH}_{3}\right)_{2}$ fragment is added. This indicates that the zinc Lewis acidity in $\mathrm{Zn}\left(\mathrm{SCH}_{3}\right)_{2}$ is high enough to induce electron transfer from the other thiolate groups to this fragment. On the opposite, addition of an anionic fragment $\left(\mathrm{Zn}_{2}\left(\mathrm{SCH}_{3}\right)_{5}{ }^{-}\right.$to $\mathbf{1}$ to form 6) induces an increase of the proton affinity.

2 and 5 are similar $\mathrm{Zn}(\mathrm{L})\left(\mathrm{SCH}_{3}\right)_{3}{ }^{-}$complexes with $\mathrm{L}$ being respectively neutral nitrogen (Im) and sulfur (from $\mathrm{Zn}(\mathrm{Im})_{2}\left(\mathrm{SCH}_{3}\right)_{2}$ ) ligands. The comparison of their reactivities (PA of 1370 and $1401 \mathrm{~kJ} / \mathrm{mol}$ for 2 and 5 respectively, see entries 2 and 6 in Table 1) indicates that a zincbound thiolate in $\mathbf{3}$ can still induce a higher nucleophilicity than does imidazole.

The range of proton affinities in solution (from $1209 \mathrm{~kJ} / \mathrm{mol}$ for $\mathbf{1}$ to $1133 \mathrm{~kJ} / \mathrm{mol}$ for 10) is much more reduced than in gas phase (from $1791 \mathrm{~kJ} / \mathrm{mol}$ for 6 to $1044 \mathrm{~kJ} / \mathrm{mol}$ for 3). We also notice that the reactivity order is partly modified compared to the gas phase order. This change is due to the fact that in solution, there is a high stabilization of the anionic sites due to the polarization of the medium. Thus charge neutralization of these structures through protonation is not as favorable as in the gas phase. As a consequence, the above noticed effects observed in the gas phase when a fragment is added to a molecule are not always reproduced in solution.

Experimental studies indicate that vertebrate MTs can react against electrophilic agents with either the $\mathrm{Zn}_{4} \mathrm{Cys}_{11}$ or the $\mathrm{Zn}_{3} \mathrm{Cys}_{9}$ clusters [34]. Our calculations indicate that $\mathbf{6}$ is slightly more nucleophilic than $\mathbf{7}$ in the gas phase but is slightly less reactive in solution. Thus these results show an approximately similar reactivity of $\mathrm{Zn}_{4} \mathrm{Cys}_{11}$ and $\mathrm{Zn}_{3} \mathrm{Cys} 9$ clusters. This is 
consistent with experimental results for which more subtle effects such as the influence of the protein environment or the accessibility of the two clusters would also play a role. The proton affinities of $\mathrm{Zn}_{4} \mathrm{Cys}_{11}$ and $\mathrm{Zn}_{3} \mathrm{Cys}_{9}$ clusters are much higher than that of $\mathrm{Zn}_{4} \mathrm{Cys}_{9} \mathrm{His}_{2}$, both in the gas phase and in solution, confirming the hypothesis that the presence of histidine residues in zinc-thiolate clusters diminishes their sulfur-center reactivity toward electrophiles [9]. Indeed, $\mathbf{8}$ is slightly less reactive than $\mathbf{2}$, model of $\mathrm{ZnHisCys}_{3} \mathrm{ZF}$, whereas $\mathbf{6}$ and $\mathbf{7}$ have approximately the same reactivity as $\mathbf{1}$, model of $\mathrm{ZnCys}_{4} \mathrm{ZF}$.

Comparing natural and synthetic zinc-thiolate clusters, we remark that there is no synthetic equivalent of the most reactive natural sites like $\mathbf{6}$ and 7. Their closer structural models, 11 and 12, are far less reactive than the MT clusters, indicating strong electronic difference between the natural sites and their synthetic models. It is indeed significant that in solution, the less reactive clusters (clusters 9-12) are all synthetic ones. We believe that this comparison enlightens the role of the MT backbone and residues, through protein packing and electrostatic screening, in stabilizing the zinc-thiolate clusters, as is the case for ZF sites [29]. Even if they are structurally rather different from MT clusters, their better electronic models are $\mathbf{1}$ and, to a lesser extent, 4, which are biological sites but also models of synthetic compounds [79][80]. 8, model of the poorly reactive cyanobacterial $\mathrm{MT} \mathrm{Zn}_{4} \mathrm{Cys}_{9} \mathrm{His}_{2}$ site, possesses approximately the same reactivity as the mononuclear sites $\mathbf{2}$ and $\mathbf{9}$. Furthermore, synthetic clusters $\mathbf{1 0}, \mathbf{1 1}$ and $\mathbf{1 2}$ show reactivity almost similar to that of $\mathbf{8}$. It is thus reasonable to believe that inorganic models of $\mathbf{8}$ will be synthesized in the future.

\section{Conclusion}

Based on the linear correlation between proton affinity and nucleophilicity of zinc-bound thiolates, we have evaluated the reactivity against electrophilic agents of a variety of monoand polynuclear zinc compounds. The relevance of this strategy is illustrated by the agreement between our calculations and the experimental results on the relative reactivity (between zinc finger sites) and selectivity (within the $\mathrm{Zn}_{4} \mathrm{Cys}_{11}$ cluster in metallothioneins) of zinc-bound thiolate alkylation. From these results, we conclude that protein packing and electrostatic screening of the $\mathrm{Zn}_{4} \mathrm{Cys}_{11}$ cluster induces selectivity between the four equivalent $\mathrm{S}_{\mathrm{t} 1}$-type sites of $\mathbf{7}$, but does not modify the relative reactivity between the different bridging and terminal thiolates. Comparison between synthetic and natural sites shows that the former are less reactive than the vertebrate MT clusters but comparatively more similar to the cyanobacterial MT $\mathrm{Zn}_{4} \mathrm{Cys}_{9} \mathrm{His}_{2}$ site. We think that this illustrates two strategies adopted by nature to kinetically stabilize these nucleophilic sites, either through steric and electrostatic 
protection from the protein environment or by Cys to His substitution into the coordination sphere of the metal.

Supporting Information Available: Cartesian coordinates and absolute electronic gas-phase and COSMO energies for all compounds.

\section{Bibliography}

[1] Sigel, A.; Sigel, H.; Sigel, R. K. O.; ed.. Metallothioneins and related chelators. metal ions in life sciences. 5. . RSC Publishing, Cambridge, 2009.

[2] Romero-Isart, N.; Vasak, M. J. Inorg. Biochem. 2002, 88, 388-396.

[3] Blindauer, C. A.; Sadler, P. J. Acc. Chem. Res. 2005, 38, 62-69.

[4] Palmiter, R. D. Proc. Natl. Acad. Sic. U.S.A 1998, 95, 8428-8430.

[5] Coyle, P.; Philcox, J. C.; Carey, L. C.; Rofe, A. M. Cell. Mol. Life Sci. 2002, 59, 627647.

[6] Arseniev, A.; Schultze, P.; Wörgötter, E.; Braun, W.; Wagner, G.; Vasak, M.; Kägi, J. H. R.; Wüthrich, K. J. Mol. Biol. 1988, 201, 637-657.

[7] Robbins, A. H.; McRee, D. E.; Williamson, M.; Collett, S. A.; Xuong, N. H.; Furey, W. F.; Wang, B. C.; Stout, C. D. J. Mol. Biol. 1991, 221, 1269-1293.

[8] Braun, W.; Vasak, M.; Robbins, A. H.; Stout, C. D.; Wagner, G.; Kägi, J. H. R.; Wüthtich, K. Proc. Natl. Acad. Sci. U.S.A 1992, 89, 10124-10128.

[9] Blindauer, C. A. J. Inorg. Biochem. 2008, 102, 507-521.

[10] Blindauer, C. A.; Harrison, M. D.; Parkinson, J. A.; Robinson, A. K.; Cavet, J. S.; Robinson, N. J.; Sadler, P. J. Proc. Natl. Acad. Sci. U.S.A. 2001, 98, 9593-9598.

[11] Peroza, E. A.; Schmucki, R.; Güntert, P.; Freisinger, E.; Zerbe, O. J. Mol. Biol. 2009, 387, 207-218.

[12] Maret, W. Biochemistry 2004, 43, 3301-3309.

[13] Maret, W. Biometals 2009, 22, 149-157.

[14] Maret, W.; Vallee, B. L. Proc. Natl. Acad. Sci. U. S. A. 1998, 95, 3478-3482.

[15] Krezel, A.; Hao, Q.; Maret, W. Arch. Biochem. Biophys. 2007, 463, 188-200.

[16] Bell, S. G.; Vallee, B. L. ChemBioChem 2009, 10, 55-62.

[17] Kröncke, K. D.; Klotz, L. O. Antioxid. Redox Signal. 2009, 11, 1015-1027.

[18] Wilcox, D. E.; Schenk, A. D.; Feldman, B. M.; Xu, Y. Antioxid. Redox Signal. 2001, 3, 549-564.

[19] Ilbert, M.; Graf, P. C. F.; Jakob, U. Antioxid. Redox Signal. 2006, 8, 835-846. 
[20] Maret, W. Antioxid. Redox Signal. 2006, 8, 1419-1441.

[21] Myers, L. C.; Terranova, M. P.; Ferentz, A. E.; Wagner, G.; Verdine, G. L. Science 1993, 261, 1164-1167.

[22] Penner-Hahn, J. Curr. Opin. Chem. Biol. 2007, 11, 166-171.

[23] Matthews, R. G.; Goulding, C. W. Curr. Opin. Chem. Biol 1997, 1, 332-339.

[24] Parkin, G. Chem. Rev. 2004, 104, 699-767.

[25] Warthen, C. R.; Hammes, B. S.; Carrano, C. J.; Crans, D. C. J. Biol. Inorg. Chem 2001, 6, 82-90.

[26] Rombach, M.; Seebacher, J.; Ji, M.; Zhang, G. F.; He, G. S.; Ibrahim, M. M.; Benkmil, B.; Vahrenkamp, H. Inorg. Chem. 2006, 45, 4571-4575.

[27] Picot, D.; Ohanessian, G.; Frison, G. Inorg. Chem. 2008, 47, 8167-8178.

[28] Wilker, J. J.; Lippard, S. J. Inorg. Chem. 1997, 36, 969-978.

[29] Maynard, A. T.; Covell, D. G. J. Am. Chem. Soc 2001, 123, 1047-1058.

[30] Huang, M. J.; Maynard, A.; Turpin, J. A.; Graham, L.; Janini, G. M.; Covell, D. G.; Rice, W. G. J. Med. Chem 1998, 41, 1371-1381.

[31] Anzellotti, A. I.; Farrell, N. P. Chem. Soc. Rev. 2008, 37, 1629-1651.

[32] Takinowaki, H.; Matsuda, Y.; Yoshida, T.; Kobayashi, Y.; Ohkubo, T. Protein Sci. 2006, 15, 487-497.

[33] Hathout, Y.; Fabris, D.; Han, M. S.; Sowder, R. C.; Henderson, L. E.; Fenselau, C. Drug. Metab. Dispos. 1996, 24, 1395-1400.

[34] Munoz, A.; Petering, D. H.; Shaw III, C. F. Inorg. Chem. 1999, 38, 5655-5659.

[35] Zaia, J.; Jiang, L.; Han, M. S.; Tabb, J. R.; Wu, Z.; Fabris, D.; Fenselau, C. Biochemistry 1996, 35, 2830-2835.

[36] Yu, X.; Wu, Z.; Fenselau, C. Biochemistry 1995, 34, 3377-3385.

[37] Antoine, M.; Fabris, D.; Fenselau, C. Drug Metab. Dispos. 1998, 26, 921-926.

[38] Almaraz, E.; de Paula, Q. A.; Liu, Q.; Reibenspies, J. H.; Darensbourg, M. Y.; Farrell, N. P. J. Am. Chem. Soc. 2008, 130, 6272-6280.

[39] Karotki, A. V.; Vasak, M. Biochemistry 2008, 47, 10961-10969.

[40] Eckschlager, T.; Adam, V.; Hrabeta, J.; Figova, K.; Kizek, R. Curr. Prot. Pep. Sci. $2009,10,360-375$.

[41] Knipp, M. Curr. Med. Chem. 2009, 16, 522-537.

[42] Picot, D.; Ohanessian, G.; Frison, G. C. R. Chimie 2009, 12, 546-553.

[43] Frenking, G.; Wagener, T.. Transition metal chemistry. In Encyclopedia of computational chemistry. Schleyer, P. V. R. (Ed.). 1998. 3073-3084. 
[44] Koch, W.; Holthausen, M. C.. A chemist's guide to density functional theory. . 2nd ed.; Wiley-VCH: Weinheim, Germany, 2000.

[45] Diedenhofen, M.; Wagener, T.; Frenking, G.. The accuracy of quantum chemical methods for the calculation of transition metal compounds. In Computational organometallic chemistry. Cundari, T. (Ed.). 2001. 69-121.

[46] Vosko, S.; Wilk, L.; Nusair, M. Can. J. Phys. 1980, 58, 1200-1211.

[47] Perdew, J. P. Phys. Rev. B 1986, 33, 8822-8824.

[48] Becke, A. D. Phys. Rev. A 1988, 38, 3098-3100.

[49] Frison, G.; Ohanessian, G. J. Comput. Chem. 2008, 29, 416-433.

[50] Amin, E. A.; Truhlar, D. G. J. Chem. Theory Comput. 2008, 4, 75-85.

[51] Sousa, S. F.; Carvalho, E. S.; Ferreira, D. M.; Tavares, I. S.; Fernandes, P. A.; Ramos, M. J.; Gomes, J. A. N. F. J. Comput. Chem. 2009, 30, 2752-2763.

[52] Pesonen, H.; Aksela, R.; Laasonen, K. J. Phys. Chem. A 2010, 114, 466-473.

[53] Sierka, M.; Hogekamp, A.; Ahlrichs, R. J. Chem. Phys. 2003, 118, 9136-9148.

[54] Ahlrichs, R.; Bär, M.; Häser, M.; Horn, H.; Kölmel, C. Chem. Phys. Lett. 1989, 162, 165-169.

[55] Schäfer, A.; Horn, H.; Ahlrichs, R. J. Chem. Phys. 1992, 97, 2571-2577.

[56] Weigend, F.; Ahlrichs, R. Phys. Chem. Chem. Phys. 2005, 7, 3297-3305.

[57] Weigend, F. Phys. Chem. Chem. Phys. 2006, 8, 1057-1065.

[58] Scott, A. P.; Radom, L. J. Phys. Chem. 1996, 100, 16502-16513.

[59] Lee, C. T.; Yang, W. T.; Parr, R. G. Phys. Rev. B 1988, 37, 785-789.

[60] Becke, A. D. J. Chem. Phys. 1993, 98, 5648-5652.

[61] Weigend, F.; Häser, M.; Patzelt, H.; Ahlrichs, R. Chem. Phys. Lett. 1998, 294, 143152.

[62] Frison, G.; Ohanessian, G. Phys. Chem. Chem. Phys. 2009, 11, 374-383.

[63] Rayon, V. M.; Valdes, H.; Diaz, N.; Suarez, D. J. Chem. Theory Comput. 2008, 4, 243-256.

[64] Sorkin, A.; Truhlar, D. G.; Amin, E. A. J. Chem. Theory Comput. 2009, 5, 12541265.

[65] Picot, D.; Ohanessian, G.; Frison, G. Chem. Asian J. 2010, , in press. DOI : 10.1002/asia.200900624.

[66] Klamt, A.; Schüürmann, G. J. Chem. Soc., Perkin Trans. 2 1993, 5, 799-805.

[67] Pan, T.; Coleman, J. E. Biochemistry 1990, 29, 3023-3029. 
[68] Bellon, S. F.; Rodgers, K. K.; Schatz, D. G.; Coleman, J. E.; Steitz, T. A. Nat. Struct. Biol. 1997, 4, 586-591.

[69] Cumberland, S. L.; Hanif, K. M.; Javier, A.; Khitrov, G. A.; Strouse, G. F.; Woessner, S. M.; Yun, C. S. Chem. Mater. 2002, 14, 1576-1584.

[70] Henkel, G.; Krebs, B. Chem. Rev. 2004, 104, 801-824.

[71] Gruff, E. S.; Koch, S. A. J. Am. Chem. Soc. 1989, 111, 8762-8763.

[72] Matsunaga, Y.; Fujisawa, K.; Ibi, N.; Amir, N.; Miyashita, Y.; Okamoto, K. Bull. Chem. Soc. Jpn. 2005, 78, 1285-1287.

[73] Burth, R.; Gelinsky, M.; Vahrenkamp, H. Inorg. Chem. 1998, 37, 2833-2836.

[74] Hagen, K. S.; Stephan, D. W.; Holm, R. H. Inorg. Chem. 1982, 21, 3928-3936.

[75] Gelinsky, M.; Vahrenkamp, H. Z. Anorg. Allg. Chem. 2002, 628, 1017-1021.

[76] Ahte, P.; Palumaa, P.; Tamm, T. J. Phys. Chem. A 2009, 113, 9157-9164.

[77] Enescu, M.; Renault, J. P.; Pommeret, S.; Mialocq, J. C.; Pin, S. Phys. Chem. Chem. Phys. 2003, 5, 3762-3767.

[78] de Courcy, B.; Gresh, N.; Piquemal, J. P. Interdiscip. Sci. Comput. Life Sci. 2009, 1, 55-60.

[79] Chung, W. P.; Dewan, J. C.; Walters, M. A. Inorg. Chem. 1991, 30, 4280-4282.

[80] Wilker, J. J.; Lippard, S. J. J. Am. Chem. Soc 1995, 117, 8682-8683. 